\title{
How Government Regulation Forces Americans Into Their Cars: A Case Study
}

Michael Lewyn

Touro Law Center, mlewyn@tourolaw.edu

Follow this and additional works at: https://digitalcommons.tourolaw.edu/scholarlyworks

Part of the State and Local Government Law Commons

\section{Recommended Citation}

16 Widener L.J. 839 (2007)

This Article is brought to you for free and open access by the Faculty Scholarship at Digital Commons @ Touro Law Center. It has been accepted for inclusion in Scholarly Works by an authorized administrator of Digital Commons @ Touro Law Center. For more information, please contact Iross@tourolaw.edu. 


\title{
HOW GOVERNMENT REGULATION FORCES AMERICANS INTO THEIR CARS: A CASE STUDY
}

\author{
Michael Lewyn* \\ I. INTRODUCTION
}

Numerous commentators have noted that the automobiledependent sprawl that dominates American cities and suburbs is a product not of the free market alone, but of government zoning regulations. ${ }^{1}$ The purpose of this paper is to explain in detail how this is so-not just by citing one or two regulations, but by showing in detail how land use regulations impose automobiledependent development upon Americans. In particular, this paper parses the Municipal Code of Jacksonville, Florida, America's most car-dependent large city, ${ }^{2}$ and unearths its most antipedestrian, antitransit provisions.

\section{ANALYSIS}

Jacksonville's Code disfavors pedestrians and transit users both through zoning laws that encourage low-density, single-use

\footnotetext{
* Assistant Professor, Florida Coastal School of Law. B.A., Wesleyan University; J.D., University of Pennsylvania.

1 See, e.g., Brannon P. Denning \& Rachel M. Lary, Retail Store SizeCapping Ordinances and the Dormant Commerce Clause Doctrine, 37 URB. LAW. 907, 910 (2005) ("[Z]oning has actually contributed to sprawl because of its focus on 'holding down densities and separating different types of uses.' " (quoting Richard Briffault, Smart Growth and American Land Use Law, 21 ST. LouIS U. PUB. L. REV. 253, 255 (2002))); Nicole Stelle Garnett, Unsubsidizing Suburbia, 90 MINN. L. REV. 459, 487 (2005) (reviewing RICHARDSON DILWORTH, THE URBAN ORIGINS OF SUBURBAN AUTONOMY (2005)) ("Exclusionary zoning and growth controls also contribute to suburban sprawl (...").

2 See U.S. Census Bureau, Statistical Abstract of the United STATES: 2004-2005, at 695 (124th ed. 2004) (finding that $92.6 \%$ of Jacksonville commuters drove alone or carpooled to work in 2000 , the highest percentage among America's twenty-five largest cities; only $2.1 \%$ of Jacksonville commuters used public transit to get to work, and only $1.8 \%$ of Jacksonville commuters walked to work).
} 
development and through parking and street design regulations that make walking unpleasant. Each of these sets of regulations will be addressed in turn.

\section{A. Jacksonville: Zoned for Sprawl}

Zoning, narrowly defined, is the regulation of land use and population density. ${ }^{3}$ Historically, American zoning law has sought to segregate housing from shopping and employment and to reduce population density ${ }^{4}$-and Jacksonville is no exception. And as will be shown below, low-density and segregated land use tends to discourage walking and public transit use.

\section{Segregation of Land Uses in Jacksonville}

Jacksonville's Code divides the city into over thirty zones, ${ }^{5}$ including seventeen residential zones and seven commercial zones. ${ }^{6}$ The city has nine separate "residential low-density" districts (including one district designated as "rural" and eight lowdensity districts), all of which are devoted primarily to single-

${ }^{3}$ For example, the Standard Zoning Enabling Act, a model state statute that has been almost universally adopted, specifically authorizes municipalities to regulate "the density of population, and the location and use of buildings." ADVISORY COMM. ON ZONING, U.S. DEP'T OF COMMERCE, A STANDARD STATE ZONING ENABLING ACT: UNDER WHICH MUNICIPALITIES MAY ADOPT ZONING REGULATIONS $\S 1$ (rev. ed. 1926) (footnotes omitted), available at http://www. planning.org/growingsmart/pdf/SZEnablingAct1926.pdf. See also Chad Lamer, Why Government Policies Encourage Urban Sprawl and the Alternatives Offered by New Urbanism, 13 KAN. J.L. \& PUB. POL'Y 391, 394 (2004) (explaining that all fifty states adopted the Enabling Act in some form) (citing Eric Damian Kelly, Zoning, in THE PRACTICE OF LOCAL GovernMENT PlANNING 251, 252 (Frank S. So \& Judith Getzels eds., 2d ed. 1988)).

${ }^{4}$ See Briffault, supra note 1, at 253 ("[H]allmarks of American land use law [include] reducing population density and dispersing residents over wider areas [as well as] the separation of different land uses from each other."); Jerry Frug, The Geography of Community, 48 STAN. L. REV. 1047, 1091 (1996) ("[V]irtually all [current zoning laws] mandate the separation of different areas by function ....").

${ }^{5}$ JACKSONVILLE, Fla., ORDINANCE CODE $\S 656.301$ (1990), available at http://www.municode.com/resources/gateway.asp?pid=12174\&sid=9.

${ }^{6}$ Id. 
family homes. ${ }^{7}$ In none of these districts are shops or offices listed as a permitted land use. ${ }^{8}$

Similarly, the city prohibits housing in some of its commercial zones. For example, the city has created a "Neighborhood Commercial" zone for businesses that "serve the daily needs of contiguous residential neighborhoods." Even though this zone exists primarily to serve people who live nearby, neither houses nor apartments are allowed in the "Neighborhood Commercial" zone. ${ }^{10}$ The city also has two "Community/General Commercial" zones, where a wider range of activities may occur ${ }^{11}$ - but again, housing is not among the permitted activities. ${ }^{12}$ Finally, the city has a separate zone for office parks - and here too housing is not allowed. ${ }^{13}$

In sum, many of Jacksonville's residents live in areas where housing is the only possible land use. If you live in one of those zones and are not particularly close to a commercial zone, you are not going to be able to walk to a store even for the simplest purchase. ${ }^{14}$ Thus, Jacksonville's zoning district regulations make Jacksonville residents more automobile-dependent.

7 JaCksonville, Fla., OrdinanCe CODE $\S$ 656.301. See also id. $\S \S$ 656.304 (stating that "single-family dwellings and mobile homes will be the predominant land uses" in "Rural Residential" district); 656.305 (stating that "single-family dwellings will be the predominant land use" in the city's "Low Density Residential" districts). In none of these districts are apartments typically allowed. Id. $\S \S 656.304(\mathrm{~A})(\mathrm{I})(\mathrm{a})$-(c) (listing permissible uses in "Rural Residential" district and not listing apartments among permitted uses); 656.305(A)(II)(a)-(c) (listing permissible uses in "Low Density Residential" districts and not listing apartments among permitted uses).

$8 \quad I d$. $\S \S 656.304(\mathrm{~A})(\mathrm{I})(\mathrm{a})$-(c) (listing permissible uses in "Rural Residential" district and not listing offices or retail among permitted uses); 656.305(A)(II)(a)-(c) (listing permissible uses in "Low Density Residential" districts and not listing offices or retail among permitted uses).

${ }^{9}$ Id. $\S 656.312$.

${ }^{10} I d$. $\S 656.312(\mathrm{~A})(\mathrm{II})(\mathrm{a})$-(c) (listing permissible uses and not mentioning single-family or multi-family dwellings among permitted uses).

${ }^{11} I d$. $\S 656.313$ (stating that these zones should contain "a wide range of retail sales and services" and usually are developed at highway intersections).

${ }_{12}^{12}$ Id. $\S 656.313(\mathrm{~A})(\mathrm{III})(\mathrm{a})-(\mathrm{c}),(\mathrm{IV})(\mathrm{a})-(\mathrm{c})$.

13 Id. $\S 656.321(\mathrm{~A})(\mathrm{I})(\mathrm{a})-(\mathrm{c})$, (II)(a)-(c) (listing permissible uses in "Business Park" districts).

${ }^{14}$ See, e.g., Terry J. Tondro, Sprawl and Its Enemies: An Introductory Discussion of Two Cities' Efforts to Control Sprawl: Ninth Gallivan Conference 


\section{How Density Regulation Makes Jacksonville Sprawl}

If you live in a residential zone but live within a block or two of a commercial street, you can walk to stores-and where residential areas are compact, quite a few people will have this opportunity. But Jacksonville's Zoning Code rigorously limits residential density. As noted above, nine of Jacksonville's seventeen residential zones are "rural" or "low-density" zones. ${ }^{15}$ In each of these zones, the city code mandates that houses use a certain amount of land-at least one or two acres in the most "rural" zone, ${ }^{16} 6000$ square feet (or slightly under .14 of an acre) ${ }^{17}$ in the most compact zone, ${ }^{18}$ and intermediate amounts of land in other low-density zones. ${ }^{19}$

Such low densities reduce the opportunities of both pedestrians and transit users. If each residence consumes large amounts of land, fewer residences can be placed within a short walk of shops or offices. Thus, antidensity regulations reduce the number of people who can live within walking distance of shops or jobs. And in low-density areas, very few people will live within

on Real Property Law April 24, 2001, 34 CoNN. L. REV. 511,517 (2001) (finding that in single-use zones, very few people "can simply walk to the local grocer .... Even if you are going to purchase a single item and the store is very close by, it is normally a car trip away").

${ }_{16}^{15}$ See supra note 7 and accompanying text.

16 JACKSONVILle, Fla., ORDINANCE CODE $\S 656.304$ (requiring a minimum lot size of either one to two acres in "Rural Residential Zone" depending on extent of sewer and water service).

${ }^{17}$ One acre contains 43,560 square feet. Tom Kuhnle, The Federal Income Tax Implications of Water Transfers, 47 STAN. L. REV. 533, 533 n.3 (1995). So a neighborhood with 6000 -square-foot houses has 7.25 houses per acre.

${ }_{18}$ JACKSONVILLE, FLA., ORDINANCE CODE $§ 656.305$ (II)(d)(2) (stating that in "Low Density Residential" districts, the minimum lot size in the most compact district is 6000 square feet).

${ }^{19} I d$. (requiring minimum lot sizes of 44,560, 21,780, 14,000, 10,800, 8800 , and 7200 square feet in various zoning districts). 
walking distance of a bus stop, ${ }^{20}$ which, in turn, means that very few people can conveniently take the bus to work. ${ }^{21}$

By contrast, more compact neighborhoods increase transportation choices because more people in an area means more potential riders within a short walking distance of a bus stop. Some commentators have suggested that a neighborhood must have at least seven or eight dwelling units per acre to support significant public transit service. ${ }^{22}$ Only 7.25 units per acre may be built in Jacksonville's most compact low-density zone, ${ }^{23}$ and even lower densities are mandated in the city's other low-density zones. ${ }^{24}$ Thus, Jacksonville's antidensity regulations mean that very few people can conveniently use the city's bus system to reach jobs or other destinations.

${ }^{20}$ Since Jacksonville has no local rail service outside downtown, the author used the term "bus" when referring to public transit. See Innovative Transp. Techs., Jacksonville's Automated Skyway Express Downtown Peoplemover, http://faculty.washington.edu/ jbs/itrans/jack.htm (last visited Apr. 14, 2007) (describing Jacksonville's rail system as a "downtown peoplemover").

${ }^{21}$ See Patrick Driscoll, San Antonio Transit System to Hold Public Hearings on Proposed Service Changes, SAN ANTONIO EXPRESS-NEWS, Nov. 12, 2002, at 8B, available at 2002 WLNR 9027324 (describing quarter mile as "convenient walk" to bus stop); Kevin Wiatrowski, Advocates Seek Faster Bus Route Expansion: Cross-County Line Slated for 2009, TAMPA TRIBUNE, Oct. 30, 2005, PASCO, at 1, available at 2005 WLNR 18123787 (quoting local transportation researcher's statement: "Given more than a quarter-mile walk to the bus stop, most people who can will drive.").

${ }^{22}$ See Robert H. Freilich, The Land-Use Implications of Transit-Oriented Development: Controlling the Demand Side of Transportation Congestion and Urban Sprawl, 30 URB. LAW. 547, 552 n.18 (1998) ("[R]esidential densities of at least 7-15 dwelling units per acre are needed in order to encourage the utilization of public transit."); Frank McDonald, Dublin's Future as a High-Rise City Discounted, IRISH TIMES (Ireland), Nov. 5, 2005, at 7, available at 2005 WLNR 17888696 ("[B]uilding at a density of eight houses per acre would only support minimal bus service."); Bill Stewart, Officials Consider Transit Proposals for Vancouver Area, THE OREGONIAN, Aug. 14, 1991, at B2, available at 1991 WLNR 4215935 (stating that "[b]us and carpooling need about eight homes per acre" for significant ridership, while rail service requires higher densities).

${ }^{23}$ See supra note 17 and accompanying text.

${ }^{24}$ See supra notes 16 and $18-19$. 


\section{B. Parking and Street Design: Why You May Have to Drive} Everywhere Even if You Live in a High-Density, Mixed-Use Zone

Of course, not all Jacksonville residents live in low-density, single-use zones. The city does have medium- and high-density residential zones $^{25}$ and allows some housing in some of its commercial zones. ${ }^{26}$ But even apartment dwellers and other residents of higher-density zones are affected by the city's parking and street design regulations-regulations that tend to make life uncomfortable for nondrivers.

\section{Parking: Drowning in the Sea of Asphalt}

Jacksonville's Code requires landlords to provide 1.5 parking spaces per unit for studio apartments with under 500 square feet of living space, 1.75 parking spaces per unit for larger studio and one bedroom apartments, and at least two spaces for larger units. ${ }^{27}$ Commercial landowners must also set aside large amounts of land for parking: most professional offices must create two off-street parking spaces for every 500 feet of office space, ${ }^{28}$ and most other businesses must create one off-street parking space for every 300 feet of floor space. ${ }^{29}$

As a result of such regulations, landowners typically surround offices, shops, and apartments with parking lots thus creating a "strip mall" effect. ${ }^{30}$ Government-mandated strip malls deter

${ }^{25}$ JACKSONVILLE, FLA., ORdINANCE CODE $\S \S 656.306$ to 656.307 (1990), available at http://www.municode.com/resources/gateway.asp?pid=12174\&s id=9. In both districts, some nonresidential uses are allowed. See id.

${ }^{26} I d$. $\S \S 656.311$ (establishing regulations for mixed-use "ResidentialProfessional-Institutional" zone); 656.315 (allowing mixed use in "Central Business District" zone).

${ }^{27} I d . \S 656.604(\mathrm{a})(2)$.

${ }^{28} \mathrm{Id}$. $\$ 656.604(\mathrm{e})(3)$.

${ }^{29}$ Id. $\S 656.604(f)(1)$. In addition, the Jacksonville Code has numerous, more specific requirements for various types of businesses. Id. $\S 656.604(\mathrm{a})-(\mathrm{f})$. The rules discussed above are the "default requirements" that generally govern Jacksonville landowners.

30 Julie Mason, Urban Reviewal: Proposed Building Laws Seek an Appealing Look, HousTON CHRONICLE, Aug. 18, 1997, at 1A, available at 1997 WLNR 6626553 (using term). In theory, parking lots could be set behind buildings rather than in front of them. However, this rarely occurs for two reasons. First, Jacksonville also requires many buildings to be set back from the 
walking and encourage driving in several ways. First, the parkingdominated "dead areas" created by minimum parking requirements discourage walking by creating landscapes that are visually unappealing for pedestrians. An Environmental Protection Agency report states that where buildings are set back behind yards of parking rather than being "flush with the sidewalk,"31 a pedestrian "has less to look at [and] feels more isolated." 32 By contrast, "small setbacks and shop-front windows provide more interesting scenery for pedestrians and create a feeling of connection between the buildings and the public spaces bordering them."33

Second, parking lots in front of buildings lengthen the commutes of pedestrians and bicyclists by increasing the distance between streets and destinations such as offices and shops. Where parking is in front of a shop, pedestrians and bicyclists cannot

street, thus, giving landowners an incentive to use the land between streets and buildings for parking rather than wasting it on uses not mandated by the city. See, e.g., JaCKSONVILle, Fla., ORDINANCE CODE $\S \S 656.312(\mathrm{~A})(\mathrm{II})(\mathrm{f})(1)(\mathrm{i})$ (explaining that buildings in "Neighborhood Commercial" district must be set back from street by twenty feet); 656.311(A)(ii)(f) (similar rule governs mixeduse district). Second, merchants may prefer to place parking in front of stores because customers find it more convenient to park there. $C f$. Dana Knight, Open-Air Shopping: Lifestyle Centers, with Array of Upscale Stores, Are Bringing Hot New Trend in Retail to Indy's Metro Area, INDIANAPOLIS STAR, July 6, 2003, at D2, available at 2003 WLNR 10918199 ("[Shopping] center is [more] convenient [when] customer[] [can] park practically in front of any store he or she wants to go in.").

${ }^{31}$ Reid Ewing, Pedestrian- And Transit-Friendly Design: A Primer FOR SMART GROWTH 10, available at http://www.epa.gov/dced/pdf/ptfd_ primer.pdf (last visited Apr. 14, 2007).

${ }^{32} I d$.

${ }^{33}$ Douglas G. French, Cities Without Soul: Standards for Architectural Controls with Growth Management Objectives, 71 U. DET. MERCY L. REV. 267, 280 (1994). For an example of shops flush with the sidewalk, see Michael Lewyn, Where I've Lived (and Visited), Avondale Shopping Center (Feb. 26, 2006), http://atlantaphotos.fotopic.net/p32879673.html. For a typical example of a Jacksonville strip mall, see Michael Lewyn, Where I've Lived (and Visited), Mandarin Strip Mall (Feb. 26, 2006), http://atlantaphotos.fotopic.net/ p32439827.html. 
approach the shop without going through an uninviting (if not downright dangerous) parking lot, dodging cars on their way. ${ }^{34}$

Third, minimum parking requirements spread sprawl by reducing density, because land devoted to parking cannot be used for housing or businesses. For example, if a city's parking code requires landlords to set aside half of their land for parking, the city is effectively reducing population density by $50 \%$.

In fact, Jacksonville's Code sometimes requires even greater reductions in density. Here is how: typically, a parking space takes up about 370 square feet. ${ }^{35}$ So Jacksonville's requirement that the owner of a 500-square-foot efficiency must provide 647 feet of parking for that unit (1.75 parking spaces times 370 square feet) ${ }^{36}$ means that an owner, who could put 2.25500 -foot units on 1147 square feet, must, instead, build one unit and one parking space-a density reduction of $54 \% .{ }^{37}$ And as noted above, ${ }^{38}$ low density reduces the number of people who can walk to bus stops, jobs, or shops; for example, an apartment complex with five or ten units per acre will support less bus service than one with twenty units per acre.

Finally, minimum parking requirements generate automobile dependence by subsidizing driving. While roads are at least partially paid for by user fees, ${ }^{39}$ parking is nearly always "free" to

${ }^{34} C f$. Freilich, supra note 22, at 557 (stating that "large expanses of asphalt devoted to parking often discourages pedestrian mobility" and makes public transit inconvenient by impeding walking to and from transit stations).

${ }^{35}$ See Richard W. Willson, Suburban Parking Requirements: A Tacit Policy for Automobile Use and Sprawl, 61 J. AM. PLAN. ASS'N 29, 37 (1995), available at 1995 WLNR 3952340.

${ }^{36}$ See supra note 27 and accompanying text (stating that the city requires 1.75 parking spaces per unit for efficiency and one bedroom apartments with 500 or more square feet).

${ }^{37}$ Jacksonville's Parking Code also reduces job density; for example, a landlord who must provide two parking spaces for every 500 square feet of office space has to set aside 740 square feet for parking (370 square feet for each parking space). See supra notes 28 and 35 and accompanying text. Thus, a landowner with 1240 square feet can only use 500 square feet for offices-a $59 \%$ density reduction.

${ }^{38}$ See supra notes 20-22 and accompanying text.

39 See Salvatore Massa, Surface Freight Transportation: Accounting for Subsidies in a "Free Market," 4 N.Y.U. J. LEGIS. \& PUB. POL'Y 285, 318-19 
its users. ${ }^{40}$ But such "free" parking is in fact paid for by landowners, who build parking lots and pass the costs of those parking lots to society as a whole in the form of higher rents, and by the landowners' business tenants, who then pass those higher rents on to society as a whole in the form of higher prices for goods and services. Thus, minimum parking requirements are essentially a type of tax that redistributes money from society as a whole to drivers. ${ }^{41}$

In sum, minimum parking requirements make even mixed-use neighborhoods more automobile-oriented by reducing density, by subsidizing driving, and by forcing pedestrians and bicyclists to waste time commuting through seas of parking in order to reach apartments, shops, and jobs.

\section{Streets for Cars, Not for People}

In addition to regulating parking and zoning, Jacksonville has a separate set of regulations governing street design. ${ }^{42}$ Jacksonville's street regulations consistently mandate wide streets and long blocks. The costs of these choices will be addressed below.

(2001) (illustrating that over half of state and federal highway spending is paid for by user fees).

40 See Willson, supra note 35 , at 30 (stating that $99 \%$ of work-related automobile trips involve free parking).

${ }^{41}$ See generally Donald C. Shoup, An Opportunity to Reduce Minimum Parking Requirements, 61 J. AM. PLAN. AsS'N. 14, 15 (1995), available at 1995 WLNR 3950745 (stating that the cost of parking space construction per driver is higher than the typical commuter's gasoline expenditures; thus, subsidy from free parking is more generous for drivers than provision of free gasoline).

${ }^{42}$ Or more accurately, Jacksonville has two sets of regulations. Privatelybuilt subdivisions are regulated primarily through section 654 of the Code, and municipal traffic engineering is governed by the city's Comprehensive Plan. See City OF Jacksonville, PlanNING \& DEVElopment DeP'T, 2010 COMPREHENSIVE Plan: TRANSPORTATION ElemENT (2005) [hereinafter COMPREHENSIVE PLAN], available at $\mathrm{http} / / /$ coj.net/Departments/Planning+and+ Development/Strategic+Planning/2010+Comprehensive+Plan.htm (follow "Transportation Element" hyperlink). The subdivision regulations incorporate the Comprehensive Plan. See Jacksonville, Fla., OrdinanCE CODE $\S$ 654.103(b) (1990), available at http://www.municode.com/resources/gateway. asp?pid=12174\&sid=9. 


\section{a) Fat Streets}

Jacksonville mandates that the largest major streets be at least 150 feet wide, ${ }^{43}$ which means that such streets may have as many as 140 feet of pavement ${ }^{44}$ and ten lanes. ${ }^{45}$ A second category of streets, "minor arterials," must be 120 feet wide, and even "collector" streets, designed to interconnect residential and commercial areas, must be 70 to 80 feet wide. ${ }^{46}$ Even by the standards of the United States, such streets are unusually wide: the typical American "principal arterial" street in an urban area has only 39 feet of pavement, and the typical American collector street in a rural area has only 24 feet of pavement. ${ }^{47}$

43 JaCksonville, Fla., ORdinANCE CODE $§$ 654.113; COMPREHENSIVE PLAN, supra note $42, \S 3.2 .2$. This classification is for "major arterials"- the most heavily trafficked streets other than limited-access highways. See JACKSONVILLE, FLA., ORDINANCE CODE $\S \S$ 654.106(ll)(6) (defining "major arterial"); 654.113 (establishing that only streets wider than major arterials are limited-access highways).

${ }^{44}$ Sidewalks on Jacksonville's nonresidential streets are typically five feet wide. JACKSONVILLE, Fla., ORDINANCE CODE $\S 654.133$ (d). So if a 150 -foot street has sidewalks on both sides of the street, the pavement can be no more than 140 feet. In addition, a street may have a few feet of landscaping between the sidewalks and the street, or between the sidewalk and the right-of-way line. Cf. Michael Southworth \& Eran Ben-Joseph, Street Standards and the Shaping of Suburbia, 61 J. AM. PLAN. Ass'N. 65, 74-76 (1995), available at 1995 WLNR 3951363 (noting that in the 1930s, the Federal Housing Administration ("FHA") recommended that streets have twenty-four feet of pavement, four feet of sidewalks, and eight feet of land reserved for plants and utilities; FHA standards adopted by many municipalities).

${ }^{45}$ The city's Comprehensive Plan provides that traffic lanes will be 16 feet wide on outside lanes and 12 feet wide for other lanes. COMPREHENSIVE PLAN, supra note $42, \S 3.1 .3$. Thus, a ten-lane street might take up 128 feet of pavement ( 32 feet for the two outside lanes and 96 feet for eight twelve-foot interior lanes), allowing 22 feet of right-of-way for sidewalks and landscaping.

${ }^{46}$ JACKSONVILLE, Fla., ORDINANCE CODE $\S$ 654.113; COMPREHENSIVE PLAN, supra note $42, \S 3.2 .2$ (streets must be 70 feet wide if they contain curbs and gutters and otherwise 80 feet wide). See also JACKSONVILLE, FlA., ORDINANCE CODE $\S 654.106(11)(1)$ (defining "collector" streets).

47 TODd LITMAN, Victoria TRANSP. POLICY INST., TRANSPORTATION Land Valuation: Evaluating Policies and Practices that affect the AMOUNT OF LAND DEVOTED TO TRANSPORTATION FACILITIES 4 (2005), available at http://www.vtpi.org/land.pdf. 
Jacksonville's wide streets discourage walking (and to a lesser extent, biking) in a variety of ways. First, a wide street lengthens pedestrian commutes because "a wide[] roadway takes longer to cross" than a narrower street. ${ }^{48}$ Second, wide streets may also be more dangerous for pedestrians because a longer commute "increase[es] the [amount of] time [a] pedestrian is exposed to traffic., ${ }^{49}$ Third, wide streets may also endanger pedestrians and bicyclists by encouraging motorists to drive faster. ${ }^{50}$ Fast traffic may increase the number of accidents because a motorist driving 30 miles per hour has a field of vision spanning about 150 degrees, while a motorist driving 60 miles per hour has a 50-degree field of vision. ${ }^{51}$ Fast traffic also increases the severity of accidents: the probability of a pedestrian being killed by an automobile is only $3.5 \%$ where the automobile is traveling 15 miles per hour, increases to $37 \%$ if the automobile is traveling 31 miles per hour, and increases to $83 \%$ if the automobile is traveling 44 miles per hour. ${ }^{52}$ Finally, wide streets require government to take more land from landowners than narrow streets, thus reducing population density by taking land that landowners could use to build housing. ${ }^{53}$ As noted above, low-density areas tend to have low levels of walking and transit use because the fewer the number of housing units that can be placed near a bus stop or other destination, the smaller the number of people who can comfortably walk to that destination. ${ }^{54}$

${ }^{48}$ Donavan v. Jones, 26,883, p. 15 (La. App. 2 Cir. 6/21/95); 658 So. $2 d$ 755,765 (stating in its description of expert testimony "a wider roadway takes longer to cross").

${ }^{49} I d$.

${ }^{50}$ See Stephen H. Burrington, Restoring the Rule of Law and Respect for Communities in Transportation, 5 N.Y.U. ENVTL. L.J. 691, 701 (1996) (stating that the government widens roads because of "solicitude toward fast traffic").

${ }^{51}$ Id. at 704 n. 50 .

${ }^{52}$ Id. at 704 .

53 See Michele Derus, Zoning Can Curb Lower-Cost Housing, THE MiLwAUKEE J. SeNTINEL, Sept. 21, 1997, available at http://calbears. findarticles.com/p/articles/mi_qn4196/is_19970921/ai_n10359570 ("Each [ten] feet of required street width reduces [housing] supply by [three] to [four] percentage points.").

${ }^{54}$ See supra notes $20-22$ and accompanying text. 


\section{b) Long Blocks}

Jacksonville limits the number of streets intersecting major streets, allowing only four intersections per mile (or one every 1320 feet) ${ }^{55}$ on "major arterials" and eight per mile (or one every 660 feet) on "minor arterials." 56 Thus, the amount of pavement between one intersection and another must be at least 660 feet long, even on "minor" arterials.

If a city has only a few intersections per mile, pedestrians have very few opportunities to cross streets and thus must spend more time trying to reach destinations between two intersections. ${ }^{57}$ By contrast, short blocks (such as the 200-foot blocks common in Portland, Oregon $)^{58}$ make it easier for pedestrians to cross streets ${ }^{59}$ and thus to reach destinations without going out of their way to do so. Thus, pedestrians benefit from short blocks and suffer from long blocks.

\section{Does Regulation Matter?}

It could be argued that Jacksonville's regulations have little effect on the city's urban form because those regulations might just mimic what the market would do without government

${ }^{55}$ There are 5280 feet in a mile. Robinson v. Arrugueta, 415 F.3d 1252, 1254 n.2 (11th Cir. 2005). So a street with four intersections per mile has one intersection every 1320 feet ( 5280 divided by four).

56 JACKSONVILLE, FLA., ORDINANCE CODE $§ 654.115$ (1990), available at http://www.municode.com/resources/gateway.asp?pid=12174\&sid=9;

COMPREHENSIVE PLAN, supra note 42, § 2.3.1.

${ }^{57}$ Jeff Gray, Police Blaming Accident Victims, Pedestrian Says, GLOBE \& MALl (Canada), Mar. 15, 2004, at A8, available at 2004 WNLR 18380258 (stating that in suburban Toronto there is "trouble for pedestrians" because of large streets that "barely allow pedestrians enough time to cross and the long blocks that provide so few safe opportunities to do so." (emphasis added)).

${ }^{58}$ See Robert Campbell, Lively City Neighborhoods Require New Blocks on the Block, BOSTON GLOBE, Jan. 13, 1991, at A4, available at 1991 WNLR 1732980. See also EWING, supra note 31, at 4 (300-foot blocks desirable for walkability); TRANSPORTATION AND GROWTH MANAGEMENT PROGRAM, MAIN STREET HANDBOOK: WHEN A HIGHWAY RUNS THRU IT 35 (1999), available at http://www.lcd.state.or.us/LCD/TGM/docs/mainstreet.pdf (200 to 400 feet ideal).

${ }^{59}$ See Gray, supra note 57 (stating that long blocks reduce opportunities to cross streets). 
interference. ${ }^{60}$ To be sure, there is no way to know exactly what a city's land-use pattern would be with less intrusive regulations. However, developers throughout the United States believe that government regulation frustrates compact, pedestrian-oriented development. ${ }^{61}$ In 2001, the Urban Land Institute ("ULI") (a developers' trade association) $)^{62}$ conducted a survey asking developers about the impact of zoning upon " 'alternatives to conventional, low-density, automobile-oriented, suburban development." "63 $85.4 \%$ of developers surveyed agreed that the supply of such development was inadequate to meet market demand, ${ }^{64}$ and $78.2 \%$ of developers identified government regulation as a significant barrier to such development. ${ }^{65}$ So, if Jacksonville resembles the rest of the United States, its regulations are an obstacle to more pedestrian-friendly development.

Moreover, Jacksonville's most walkable neighborhoods have experienced significant price appreciation-evidence that there may be substantial unmet demand for such environments. In San Marco and Riverside, two older, relatively walkable areas, ${ }^{66}$ property values increased by $50 \%$ and $68 \%$, respectively, between

${ }^{60}$ Cf. ROBERT BruegmanN, Sprawl: A COMPACT History 105 (2005) (suggesting that this is generally the case in United States).

61 See Jonathan LeVINe, Zoned OUt: Regulation, Markets, and CHOICES IN TRANSPORTATION AND METROPOLITAN LAND-USE 128-29 (2006).

${ }^{62}$ Id. at 125 (describing ULI as "the premiere national organization of land developers").

${ }^{63}$ Id. at 126.

${ }^{64}$ Id. at 128.

${ }^{65} \mathrm{Id}$. at 129.

${ }^{66}$ See Lori Boyer, Visioning for the Future, SAN MARCo TIMES, (San Marco Pres. Soc'y, Jacksonville, Fla.), Spring 2006, at 1, 1 available at http://www.sanmarcopreservationsociety.com/documents/SMPSspringNL.pdf (describing San Marco as a "highly desirable, walkable gathering place"); Victoria R. Freeman, Letter to the Editor, Walkers Rule, FLA. TIMES-UNION, Jan. 23, 2006, available at http://www.jacksonville.com/tu-online/stories/ 012306/opl 20884671.shtml (describing Riverside as one of the city's "most walkable areas"). To see photos of these neighborhoods and to see how they compare with more typical Jacksonville neighborhoods, see Michael Lewyn, Where I've Lived (and Visited), Feb. 26, 2006, http://atlantaphotos.fotopic.net/ c872477.html. 
1992 and $2001^{67}$-an appreciation rate higher than the $37 \%$ regionwide appreciation rate during that period. ${ }^{68}$

\section{CONCLUSION}

Attempts to reform urban sprawl are often met with charges that critics of the status quo seek "to force people out of their cars. " ${ }^{\circ 9}$ But in Jacksonville, the government arguably forces people into their cars through heavy-handed zoning, parking, and street design regulation: not just through traditional zoning regulations directly limiting land use and density, but also by enacting parking and street design regulations that force pedestrians to go out of their way to cross the street, by making those streets too wide to be easily crossed, and by mandating the creation of moats of parking between those streets and the ultimate destination of a pedestrian or bicyclist.

${ }^{67}$ See Timothy McLendon \& JoAnn Klein, Comparative Property Values Analysis: Use of GIS Mapping to Review Property Appraisal Data, in ECONOMIC IMPACTS OF HISTORIC PRESERVATION IN FLORIDA VII-1, VII-12 (2002), available at http://www.law.ufl.edu/cgr/pdf/Tech-Chapter7.PDF.

68 See Nat'l Ass'n of Home Builders, NAHB/Wells Fargo Housing Opportunity Index (HOI), http://www.nahb.org/page.aspx/category/sectionID $=135$ (follow the "1/6/05 The NAHB/Wells Fargo Housing Opportunity Index: Annual History (1991-2003)" hyperlink) (last visited Apr. 17, 2007) (showing that the median housing price in Jacksonville increased from $\$ 78,000$ to $\$ 124,000$ between 1992 to 2001).

${ }^{69}$ Clint Bolick, Subverting the American Dream: Government Dictated "Smart Growth" Is Unwise and Unconstitutional, 148 U. PA. L. REV. 859, 866 (2000) (asserting that Portland's anti-sprawl policies seek "to force people out of their cars"). See also John Carlisle, The Campaign Against Urban Sprawl: Declaring War on the American Dream, NAT'L POL'Y ANALYSIS (1999), http://www.nationalcenter.org/NPA239.html ("To stop sprawl means to force people out of their cars."). A search of the quote "force people out of their cars" on the Google.com search engine revealed 14,800 uses of this catchphrase. (last conducted Apr. 14, 2007). 